\title{
REVISITING THE RELATION BETWEEN ENVIRONMENTAL PERFORMANCE AND FINANCIAL PERFORMANCE
}

\author{
Rizqy Aiddha Yuniawati \\ Universitas Airlangga, Banyuwangi, Indonesia \\ Email: rizqy.aiddha.y@feb.unair.ac.id
}

\begin{abstract}
This study aims to determine the effect of environmental performance on corporate financial performance. The method used in this research is a descriptive research method with a quantitative approach. The population in this study are textile companies listed on the Indonesia Stock Exchange. The sampling technique in this study uses purposive sampling, which is a textile company that is listed on the Indonesia Stock Exchange and publishes financial statements in 2017-2018 and has participated in the Company Performance Rating Program. The type of data used is secondary data with the documentation data collection method from the official website of the Indonesia Stock Exchange. The analysis tool used is linear regression. Environmental performance is measured by the company's performance in the PROPER (environmental performance rating program in environmental management). Financial performance is measured by returns on assets (ROA). Based on research result, it can be concluded that environmental performance has not significant effect on the company's financial performance. This study contributes to the environmental accounting literature especially for sustainable development. This study is expected to provide considerations to further increase awareness of environmental performance by making accurate disclosure principles.
\end{abstract}

Keywords: environmental accounting, financial performance, return on assets (ROA), textile companies

ARTICLE INFORMATIONS

Article history: submitted: 22 Juli 2020; revised: 25 November 2020 ; accepted: 2 Desember 2020

JEL Classifiction: Q56

How to cited: Yuniawati, Rizqy A. (2020). Revisiting The Relation between Environmental Performance and Financial Performance. JIAFE (Jurnal IImiah Akuntansi Fakultas Ekonomi), 6(2), 139148. https://doi.org/10.34204/iiafe.v6i2.2217

Copyright@2020. JIAFE (Jurnal Akuntansi Ilmiah Fakultas Ekonomi) Universitas Pakuan

\section{INTRODUCTION}

The question of environmental performance regarding the company's financial performance is an issue that will be discussed all the time. The debate took place between the researchers and the business community. Are they applying the concept of environmentally friendly to care about the environment or to benefit? Some people argue that go green is more expensive because the design and system must be changed to be environmentally friendly (Russell et al., 2017). However, some others believe that the capital markets reward companies who think about environmental performance. With increasing concern for the environment, a positive image of the company will be formed so that it can attract the attention of stakeholders and the public who use financial reports. The view that company that have excellent environmental performance and disclosure of useful company information is also expected to be considered by investors to invest. Consequently, environmental performance has a positive impact on financial performance.

Several studies that have been conducted with environmental performance and financial performance variables have shown varying results. Some studies show a 
significant positive relationship, while others are not significant. Some of the research that has been conducted comes from developed countries whose people have high environmental awareness. Nevertheless, several studies that have been conducted with environmental performance variables come from developing countries. This is due to the lack of public awareness of the environment so that the determination of environmental performance measurement is low.

This research was conducted in Indonesia with attention to the phenomenon of global warming and environmental damage today, where getting more attention and as an important issue. Human activity is recognized as a significant driver in global environmental change, namely the development of the industrial sector (Russell et al., 2017). Along with the development of the industrial sector, many negative impacts are found caused by human activities. On the other hand, the growth of the industrial sector has a positive impact, namely increasing employment, so that economic growth will automatically increase. However, on the other hand, there are negative impacts that arise and affect environmental sustainability, when factories ignore the preservation of the natural environment by dumping liquid waste into rivers without an environmentally sound waste treatment process. This will undoubtedly harm humans and also the ecosystem around the environment. It seems that more considerable attention to environmental problems will lead to increased costs and can reduce profits (Magara et al., 2015).

A negative impact of the growth of the industrial sector in terms of use chemicals or chemical compounds that will damage the ozone layer, which is suspected to be getting thinner. Ozone is natural gas in the atmosphere that functions to absorb most of the solar radiation, which is very dangerous for living things, especially ultraviolet. Environmental damage is getting worse as a result of global warming triggered by the greenhouse effect and human behaviour that is not friendly to the surrounding environment, to deal with environmental cases can be limited and analyzed by the authorities integrated with environmental policies, namely by starting to develop sustainable and environmentally friendly businesses (Dascalu et al., 2010; Health Crisis Center, 2016). The growth of the industrial sector that considers environmental sustainability is a necessity directed at development that balances ecological/environmental, economic, and social aspects (Hussain et al., 2016). This is also in line with the triple bottom line concept consisting of profit, planet, people, or 3P (Elkington, 1999).

Nath and Ramanathan (2016) explain that one factor of which has a role in environmental performance is environmental accounting. Environmental accounting role can refer to one of the accounting roles, namely as a provider of information for management. However, traditional management accounting systems more often generalize indirect costs, including environmental costs, into overhead costs, making them hidden and managers having difficulty tracking and controlling these costs (Dascalu et al., 2010). With environmental accounting, specifically environmental management accounting (EMA), identification of environmental costs, appropriated and allocated appropriately to products or processes, thus enabling management to look for opportunities for cost savings (Saeidi et al., 2018). EMA also provides information on the physical flow of materials, energy, and water used and waste and emissions produced, making it easier for management to manage the environment to improve environmental performance (Magara et al., 2015). One component of the accounting system is environmental accounting. Conventional environmental accounting measures is more likely to measure environmental performance 
against corporate finance. While environmental accounting measures the impact of a company based on the environment, but measurements are made in the form of physical units, but the measurement standards used are not in the form of monetary units.

The company's financial performance is a part of conventional environmental accounting that will measure environmental impacts in financial terms. The company's annual financial report is a description of the financial performance of a company's success. To find out the company's financial performance appropriately, many performance measurement has been made and determined by management and stakeholders. To measure company performance can be done by analyzing financial condition, which is reflected in financial ratios.

It can be concluded that financial performance is a positive signal for owners of capital. Suppose the calculation of the ratios to the financial statements give positive or good results, then the capital owner will invest their capital, vice versa if from the measurement of the ratios of the financial statements give wrong results. The capital owner will rethink investing (Nath and Ramanathan, 2016). In the current era of market economics, demanding the realization of the right economic performance conditions not only demands the creation of financial reports that provide positive results for the company but also needs to be accompanied by ethical financial performance behaviours. The demand for ethical, economic performance has implications for the realization of industrial activity as a harmonious interaction between stakeholders (interested parties) and shareholders or business people themselves. Therefore, all business actions and financial performance is an indicator of stakeholder assessment.
The company's responsibility towards the environment will have an impact on financial performance. This is due to companies that have excellent environmental performance, indirectly have excellent social information to upgrade the image of the company; this is following the postulate of the theory of legitimacy, which states that companies that good environmental performance will be proportional to their financial performance.The view that a company that performs excellent environmental performance and disclosure of useful company information is also expected to be considered by investors to invest. Investors not only look at the company's performance in financial terms but also the environmental performance carried out needs to be considered. This shows that companies that conduct social responsibility disclosures through annual reports get a positive response from market participants. This is done to obtain social legitimacy and maximize its financial strength in the long run (Deegan, 2019).

In Indonesia, there are several companies whose financial performance tends to decline, as stated by Sudradjat as Chairperson of the Indonesian Textile Association (API) that the growth of the financial performance of the Textile and Textile Products industry fell by $2 \%$, both in the domestic and export markets. One factor that can cause financial performance to decline is environmental accounting disclosure. Companies that have excellent environmental performance will disclose their environmental accounting reporting adequately, and companies that manage excellent environmental performance will also have good financial performance (Russell et al., 2017). Some of the environmental damage that occurs is evidence that environmental accounting disclosures in Indonesia are still very poor. One industrial sector that has waste disposal and environmental accounting 
disclosures are still weak, namely the textile industry. According to Sudradjat as chairman of the Indonesian Textile Association (API), out of 600 textile and textile products industries in the Citarum watershed, only $10 \%$ have operated WWTPs (wastewater management installations) according to standards (Sudradjat, 2011). This is reinforced by the statement of Nopiansyah (2019), which states that the increase in the level of textile production in Indonesia is balanced with environmental pollution rates. In this regard, many parties expect that companies in Indonesia and even throughout the world must start developing sustainable and environmentally friendly businesses.

Companies that are used as populations are companies engaged in the textile sector. Textile companies are chosen because these types of companies, besides producing solid waste, also produce liquid waste. Liquid waste contains various hazardous substances, including heavy metals, halogenated hydrocarbons, pigments, dyes, organic solvents, acidic wastes, and acidic bases. Samples taken were textile companies listed on the Indonesia Stock Exchange and participated in PROPER. Researchers determine the 2017-2018 research year because they see the latest cases of environmental pollution caused by textile production in 2019.

Textile companies assessed by the Ministry of Environment during 2017-2018 experienced ups and downs in environmental management. In 2019 there are still many textile companies listed on the Indonesian Stock Exchange in the red rank, including PT Sulindafin, PT Samitex Sewon, PT Century Textile Industry, and there are still several other companies. The red rating means that there are still many companies that do not conduct environmental management following existing regulations.

Gitman and Zutter (2015) found that financial performance is the result of all activities carried out in utilizing the financial resources owned. In other words, the company's financial performance is an impact that has been implemented by management in a sustainable manner, so the company's or management's overall performance can be assessed. Profitability is one of the benchmarks in a company to raise profits concerning sales, total assets, and its capital. There are several profitability ratios, including gross profit margin, net profit margin, return on assets, return on equity, and operating profit margin. However, in this study, researchers measured financial performance using profitability ratios measured by Return on Assets (ROA). Winarno (2019), namely: 1) Is a comprehensive measurement indicator to see the state of a company based on financial statements 2) Easy to calculate, understand, and very meaningful in absolute value 3 ) Serves as a denominator that represents profits and business units.

The next sub-section of this article will discuss hypotheses development, the relationship of several theories that can explain the effect of environmental performance on financial performance. It is hoped that the results of this study can be used as one of the constructive inputs in creating a better environment, as well as providing information in making policies related to improving the company's financial performance.

\section{LITERATURE REVIEW AND RESEARCH DEVELOPMENT}

Research conducted by Solovida and Latan (2017) found that the quantity and quality of accounting information disclosure have a negative relationship with financial performance. This is contrary to expectations; several studies have found a significant positive relationship between disclosure of accounting information on financial performance. The author has also considered several biases in the disclosure of accounting information that can explain this result. 
The result of research by Al-Tuwaiji et al. (2004) stated that environmental performance has a significant relationship to financial performance that can be measured from specific pollution actions and problems. Several studies use environmental performance variables that have a relationship with economic performance. Among those who have found a positive relationship is a research by Magara et al. (2015) and Luh et al., (2017). The other research by Freedman and Jaggi (1992) and Putra (2018) discovered that the environmental performance variable on financial performance has no significant relationship. Subsequent research states that environmental performance does not affect financial performance; this is consistent with traditional economic thinking which shows trade-off between corporate profits or environmentally friendly action by corporate (Freedman and Jaggi, 1992).

Much research is conducted in developed countries, this is due to the high environmental awareness of stakeholders and environmental performance measurement that has long been applied. Companies will be left behind if they are only concerned with company profits without having environmental responsibility (Deswanto and Siregar, 2018). Research in Singapore shows that there is no pressure from the government on organizations to environmental impact (Apergis and Ozturk, 2015). One of the studies conducted in Malaysia found that there were high environmental costs and a lack of awareness among company stakeholders (Hussain et al., 2016). This is due to low stakeholder awareness of the environment and a lack of accurate measurement of environmental performance (Solovida and Latan, 2017). It is well known to the public that Indonesia is one of the countries that lacks transparency, monitoring, and governance, so the government's environmental rating (PROPER) has raised questions about independence and reliability (Fajarini et al., 2018).

This study determines the environmental performance as an independent variable and financial performance as dependent variable.

$\mathrm{H}_{1}$ : Environmental Performance has a positive effect on Financial Performance.

\section{RESEARCH METHOD}

The population in this study are textile companies listed on the Indonesia Stock Exchange in 2017- 2018. Sampling in this study using a purposive sampling method. The sample criteria used in this study are (1) textile companies that publish and publish annual reports in the period 2017-2018, (2)Textile companies that have participated in PROPER in environmental management in the period 2017- 2018. The final sample in this study obtained 12 sample companies from 73 textile companies on the Indonesia Stock Exchange according to the sample selection criteria. The test tool used in this study is a simple linear regression test.

This research consist of two variables, i.e the independent variable and the dependent variable. The independent variable used is environmental performance. To measure environmental performance in Indonesia, companies can use PROPER. PROPER is one of the efforts made by the Ministry of Environment (KLH) with the aim of encouraging corporate governance in environmental management. The dependent variable in this study is financial performance. Financial performance is an indicator of a company's financial health over a specified period. A company's financial performance can be measured in a variety of different ways, including profits, measuring returns, market share growth, investment returns, equity returns, and liquidity (Magara et al., 2015). In this study, financial performance is measured using return on assets (ROA). ROA was chosen because it has several advantages, including 
the following advantages Winarno (2019), namely: 1) Is a comprehensive measurement indicator to see the state of a company based on financial statements 2) Easy to calculate, understand, and very meaningful in absolute value 3 ) Acts as a denominator that impacts the business unit and company profits.

The documentation method is a data collection method used in this study, the data collected is secondary data in the form of company financial statements and data on environmental performance based on the PROPER program obtained from the Ministry of Environment (KLH). The data used in this study are secondary, namely data from textile companies that go public in the period 20172018 from the Indonesia Stock Exchange. Data on environmental performance was obtained from the Ministry of Environment (KLH) database. In contrast, the stock price was obtained from IDX-Statistics on the Indonesia Stock Exchange in 2017-2018, which was then processed according to research needs. The analytical tool used is simple linear regression analysis.

\section{Environmental Performance}

Several studies have been conducted using several methods to measure environmental performance. Russell et al. (2017) and Saeidi et al. (2018) use the UK MAC company's index of reputation published in Management Today as a proxy to measure the company's environmental performance. However, other researchers use different sizes. As an example, Freedman and Jaggi (1992) provide advice to operating companies to think more about environmental performance.

According to Solovida and Latan (2017), company environmental performance measures must be appropriate to attract stakeholders to relevant information. The information needed by a researcher is an action that has been taken in dealing with environmental performance; this information is especially important for those undertaking studies in developing countries. In Indonesia, the company's environmental performance can be demonstrated by PROPER, which is one of the efforts made by the Ministry of Environment (KLH) with the aim of encouraging corporate governance in environmental management. The implementation of PROPER aims to strengthen environmental governance. PROPER also aims at transparency and public awareness of environmental management as referred to in article 65 paragraph (2) and (4) of the Law. No. 32 of 2009 concerning Environmental Protection and Management related to the access and role of everyone in environmental protection and management. The results of the PROPER rating assessment will be published publicly to the public and other stakeholders, so company performance is grouped into color ratings. Through this color ranking, it is hoped that the community can more easily understand the performance of each company. The color rating criteria in PROPER are as follows.

Table 1. PROPER Ranking Criteria

\begin{tabular}{l|l|l}
\hline \multicolumn{1}{c|}{$\begin{array}{c}\text { Color } \\
\text { Indicator }\end{array}$} & \multicolumn{1}{c|}{ Information } & Score \\
\hline Gold & $\begin{array}{l}\text { Superior in the } \\
\text { production process. }\end{array}$ & 5 \\
\hline Green & $\begin{array}{l}\text { As per the requirement } \\
\text { in the regulations }\end{array}$ & 4 \\
\hline Blue & $\begin{array}{l}\text { In accordance with the } \\
\text { conditions required }\end{array}$ & 3 \\
\hline Red & Not yet eligible & 2 \\
\hline Black & $\begin{array}{l}\text { Deliberately doing } \\
\text { something that violates } \\
\text { the provisions }\end{array}$ & 1 \\
\hline
\end{tabular}

Source: PROPER report for 2019

\section{Financial Performance}

Financial performance is a picture of a company's financial condition that is analyzed by financial analysis tools. In this study to measure financial performance using Return on Assets (ROA). The following is the Return on Assets (ROA) formula: 
$R O A$

$=\frac{\text { Net Profit Before Tax }}{\text { Total Assets }} \times 100 \%$

\section{RESULT AND DISCUSSION}

Here is the table of $R$ square test result.

Table 2. Model Summary

\begin{tabular}{c|c|c|c|c}
\hline Model & $R$ & $\begin{array}{c}\mathrm{R} \\
\text { Square }\end{array}$ & $\begin{array}{c}\text { Adj. R } \\
\text { Square }\end{array}$ & $\begin{array}{c}\text { Std. The } \\
\text { error of the } \\
\text { Estimate }\end{array}$ \\
\hline 1 & $0,192 \mathrm{a}$ & 0,037 & $-0,059$ & 8,7670 \\
\hline
\end{tabular}

a. Predictors: (Constant), Environmental Performance

The table above explains the value of the correlation $(r)$ is 0,192 . From the output obtained a coefficient of determination ( $R$ square) of 0,037 , which implies that the influence of the independent variable (environmental performance) on the dependent variable (financial performance) is $3,7 \%$.

Table 3. F Test ANOVA

\begin{tabular}{l|c|c}
\hline \multicolumn{1}{c|}{ Model } & F & Sig. \\
\hline $\begin{array}{l}\text { Regression } \\
\text { Residual } \\
\text { Total }\end{array}$ & 0,383 & $0,550 \mathrm{~b}$ \\
\hline
\end{tabular}

a. Dependent Variable: Financial Performance b.Predictors: (Constant), Environmental Performance

From the output it is known that the calculated $F$ value $=0,383$ while the $F$ table at a significance of $5 \%$ or 0.05 using the formula F Table $=(k ; n k)=(1 ; 11)$ is 4,84 . Then when viewed from the significance level of 0,577. Then it can be concluded that the calculated $\mathrm{F}$ $(0,383)<F$ table $(4,84)$ and the significance value $(0,550)>0,05$, then the hypothesis is rejected, or in other words, the environmental performance has no effect on financial performance in ROA.
Tabel 4. Coefficients

\begin{tabular}{l|c|c|c}
\hline \multicolumn{1}{c|}{ Model } & B & t & Sig. \\
\hline 1 (Constant) & - & $-0,562$ & 0,587 \\
Environmental & 10.900 & 0,618 & 0,550 \\
Performance & 4.200 & & \\
\hline
\end{tabular}

a. Dependent Variable: Financial Performance

The constant value (a) of -10.900 is known, while the PROPER value for environmental performance (b / regression coefficient) is 4.200 , so the regression equation can be written:

$$
Y=-10.900+4.200 x
$$

The equation can be translated: 1) constant of -10.900 implies that the consistent value of the financial performance variable is $-10.900,2$ ) regression coefficient $X$ of 4.200 states that every $1 \%$ increase in the value of environmental performance, the value of financial performance increases by 4.200. The regression coefficient is positive, so it can be said that the direction of the effect of variable $\mathrm{X}$ on $\mathrm{Y}$ is positive.

In making decisions in a simple regression test, when seen from the results of the significance value from the Coefficients table obtained a significance value of $0,550>$ 0,05 , so it can be concluded that the environmental performance variable does not affect financial performance variables measured by ROA. Whereas, if seen from the $t$ value, it is known that the $\mathrm{t}$ value is $0,618<\mathrm{t}$ table 2,2221414 , so it can be concluded that the environmental performance variable does not affect the financial performance variable. The results of this study are in accordance with the study by Freedman and Jaggi (1992) and Putra (2018), which found that environmental performance did not have a significant effect on financial performance. One reason for this is that it is consistent with traditional economic thinking that illustrates this relationship as a trade-off between a 
company's profitability and its social responsibility actions (Freedman and Jaggi, 1992).

Based on the sample taken, the average company gets a red rating which indicates that most companies do not care about the environment. The implementation of environmental practices could have an important effect on the financial performance of a firm, because the profitability could be decreased by high production costs linked to environmental innovation according to neoclassical economic theory. However, from a natural-resource-based view and instrumental stakeholder theory, the adoption of environmental practices by core business strategy allows firms to save production costs by reducing environmental risks, while enhancing their relationship with the key stakeholders, which contributes to achieving competitive advantages and thus improves their corporate financial performance in the long term.

Research conducted in Indonesia, as an example of a developing country, shows that environmental performance does not have a significant effect on financial performance. This means that the PROPER ratings do not affect the good or bad of the company's financial performance in textile companies that have been listed on the Indonesia Stock Exchange. This is presumably because conditions in Indonesia are very different from other countries, especially western countries, related to the behavior of capital market players in Indonesia. Capital market players in western countries tend to respond to all kinds of information relating to the companies where capital market players invest (Russell et al., 2017).

In this study, it is likely that there are still many capital market players who do not pay attention to the environmental performance ranking (PROPER) information issued by the Ministry of Environment regarding the company's environmental performance. So that capital market practitioners still have not shown a response or used the environmental performance rating information (PROPER) issued by the Ministry of Environment in making their investment decisions. This resulted in no significant positive relationship between financial performance and environmental performance. Researchers suspect there are still other variables used by capital market players in Indonesia in determining investment portfolios in textile companies listed on the Indonesia Stock Exchange, such as macro conditions, financial ratios, investment risks, and others.

An investor's perception will influence their investment attitude and behavior. thus, investors' perceptions can influence corporate behavior. When stakeholders pay attention to ethical and environmental factors, company behavior will lead to better environmental performance. investors must be educated that investors are a key role in corporate behavior. This is also related to the stakeholder theory which states that the company has a responsibility to stakeholders by carrying out social disclosures.

\section{CONCLUSION}

This study aims to determine the effect of environmental performance on corporate financial performance. This study result concluded that the environmental performance has not significantly impacted on the company's financial performance measured by ROA. This shows that although companies in Indonesia improve their environmental performance according to the specified limits, it will not affect the company's financial performance. This is because companies in Indonesia are unable to carry out environmental innovation and environmental performance itself is not good enough. This means that environmental performance is not the only factor causing high or low financial performance, as indicated by Return on Assets (ROA). This study 
contributes to the environmental accounting literature especially for sustainable development.

Financial performance is a symbol that the company can operate well. The results show that environmental performance has no effect on the company's financial performance, indicating that it shows that although the company has carried out environmentally friendly production, it will not affect the company's financial performance. The possibility that what happens is weak public awareness and inaccurate environmental performance measurement. This study is expected to provide considerations to further increase awareness of environmental performance by making accurate disclosure principles.

\section{REFERENCES}

Al-Tuwaijri, S. A., et al. (2004). The relations among environmental disclosure, environmental performance, and economic performance: A simultaneous equations approach. Accounting, Organizations and Society, 29(5-6), 447471.

Apergis, N., and Ozturk, I. (2015). Testing environmental Kuznets curve hypothesis in Asian countries. Ecological Indicators, $52,16-22$.

Dascalu, C., et al. (2010). The externalities in social environmental accounting. International Journal of Accounting and Information Management, 18(1), 19-30.

Deegan, C. M. (2019). Legitimacy theory: Despite its enduring popularity and contribution, time is right for a necessary makeover. Accounting, Auditing and Accountability Journal, 32(8), 2307-2329.

Deswanto, R. B., and Siregar, S. V. (2018). The Associations Between Environmental Disclosures With Financial Performance, Environmental Performance, And Firm
Value. Social Responsibility Journal, 14(1), 180-193.

Elkington, J. (1999). Triple bottom-line reporting: Looking for balance. Australian CPA.

Fajarini, I., et al. (2018). Characteristic and Environmental Disclosure of ASX Listed Companies. E3S W Eb of Conferences, $24,73$.

Freedman, M., and Jaggi, B. (1992). An investigation of the long-run relationship between pollution performance and economic performance: The case of pulp and paper firms. Critical Perspectives on Accounting, 3(4), 315-336.

Gitman, L. J., and Zutter, C. J. (2015). Principles of Managerial Finance 14th Edition. In Prentice Hall.

Hussain, M. D., et al. (2016). Environmental Accounting and Sustainable Development: an Empirical Review. International Journal of Business and Technopreneurship (IJBT), 6(2), 335350.

Luh, N., et al. (2017). Pengaruh Kinerja Lingkungan Pada Kinerja Keuangan Dengan Corporate Sosial Responsibility Sebagai Variabel Intervening. E-Jurnal Akuntansi, 20(1), 645-673.

Magara, R., et al. (2015). Effect of Environmental Accounting on Company Financial Performance in Kisii County. British Journal of Economics, Management and Trade, 10(1), 1-11.

Nath, P., and Ramanathan, R. (2016). Environmental management practices, environmental technology portfolio, and environmental commitment: A content analytic approach for UK manufacturing firms. International Journal of Production Economics, 171, 427-437.

Nopiansyah, R. (2019). Naiknya Tingkat Produksi Tekstil di Indonesia yang di Imbangi dengan Angka Pencemaran 
Lingkungan. IATEK UNSRI. https://iatekunsri.com/artikel/keteknikk imiaan/539-naiknya-tingkat-produksitekstil-di-indonesia-yang-di-imbangidengan-angka-pencemaran-lingkungan, [diakses : 22 Maret 2020]

Putra, Y. P. (2018). Pengaruh Kinerja Lingkungan Terhadap Kinerja Keuangan Dengan Pengungkapan Corporate Social Responsibility (CSR) Sebagai Variabel Intervening. BALANCE Jurnal Akuntansi Dan Bisnis, 2(2), 227.

Russell, S., et al. (2017). Accounts Of Nature And The Nature of Accounts: Critical Reflections On Environmental Accounting And Propositions For Ecologically Informed Accounting. Accounting, Auditing and Accountability Journal, 30(5).

Saeidi, S. P., et al. (2018). The Moderating Role Of Environmental Management Accounting Between Environmental Innovation And Firm Financial
Performance. International Journal of Business Performance Management, 19(3), 326.

Sudradjat, A. (2011, April 27). Dilema Industri Tekstil.

https://ekonomi.kompas.com/read/201 1/04/27/11034054/dilema.industri.teks til?page=all, [diakses pada 22 Maret 2020].

Solovida, G. T., and Latan, H. (2017). Linking environmental strategy to environmental performance: Mediation role of environmental management accounting. Sustainability Accounting, Management and Policy Journal, 8(5), 595-619.

Winarno, S. H. (2019). Analisis NPM, ROA, dan ROE dalam Mengukur Kinerja Keuangan. Jurnal STEI Ekonomi, 28(02), 254-266.

www.idx.co.id, [diakses pada 27 Maret 2020]

http://proper.menlhk.go.id/, [diakses pada 22 Maret 2020] 